\title{
EFEKTIFITAS PENERAPAN METODE STRUCTURAL ANALITYCAL SYNTHETIC (SAS) DALAM MENINGKATKAN KETERAMPILAN MEMBACA PESERTA DIDIK KELAS I MI NURUL ISLAMIYAH KEMANG
}

\section{EFFECTIVENESS OF THE IMPLEMENTATION OF SYNTETIC ANALITYCAL STRUCTURAL (SAS) IN IMPROVING THE STUDENTS' READING SKILL OF THE FIRST GRADE AT MI NURUL ISLAMYAH KEMANG}

\author{
Nursela $^{1}$, Hidayah Baisa ${ }^{2}$, Tjetjep Suhandi ${ }^{3}$ \\ ${ }^{1,2,3}$ Fakultas Agama Islam Universitas Ibn Khaldun Bogor \\ 1,2,3J1. Sholeh Iskandar KM.2 Bogor 16162 telp/fax. 02518356884 \\ Email: nursela220@gmail.com ${ }^{1)}$, hidyusuf@yahoo.co.id ${ }^{2)}$, suhandicecep1@gmail.com ${ }^{3)}$
}

\begin{abstract}
Abstrak
Tujuan penelitian ini adalah untuk mengetahui efektifitas penerapan metode Structural Analitycal Synthetic (SAS) dalam meningkatkan keterampilan membaca. Penelitian ini dilaksanakan di kelas I MI Nurul Islamiyah Kemang. Penelitian dilakukan dalam tiga siklus setiap siklusnya terdiri dari empat tahap yaitu perencanaan (plan), pelaksanaan (act), observasi (observe), dan refleksi (reflect). Pengumpulan data yang dilakukan menggunakan tes, observasi dan dokumentasi yang dianalisis secara kualitatif dan kuantitatif. Hasil penelitian menunjukkan bahwa metode Structural Analitycal Synthetic (SAS) efektif digunakan dalam pembelajaran membaca yang ditunjukkan oleh hasil observasi aktivitas guru dengan presentase siklus $\mathrm{I}=65,28 \%$, siklus II $=91,67 \%$, dan siklus III $=100 \%$. Hasil observasi aktivitas peserta didik dengan presentase siklus $\mathrm{I}=74,44 \%$, siklus II $=76,67 \%$, dan siklus III $80 \%$. Sementara peningkatan keterampilan membaca peserta didik diperoleh dari rata-rata hasil posttest, pra siklus $=68,14 \%$ dengan presentase ketuntasan $46,43 \%$, siklus I $=77,53 \%$ dengan presentase ketuntasan $67,86 \%$, siklus II $=87,11 \%$ dengan presentase ketuntasan $89,29 \%$, dan siklus III $=91,39 \%$ dengan presentase ketuntasan $100 \%$ dari 28 peserta didik. Dengan demikian dapat disimpulkan bahwa metode structural analitycal synthetic (SAS) efektif digunakan dan dapat meningkatkan keterampilan membaca peserta didik kelas I MI Nurul Islamiyah Kemang.
\end{abstract}

Kata Kunci: Efektifitas, Metode Structural Analitycal Synthetic (SAS), Keterampilan, Membaca.

\begin{abstract}
The purpose of this study was to know the effectiveness of applying Structural Analitycal Synthetic (SAS) method in improving reading skill. This research was conducted in grade I MI Nurul Islamiyah Kemang. Research done cycle each cycle consist of four stages of planning, action, observation, and reflection. Data collection conducted using test, observations and documentations that are analyzed qualitatively and quantitatively. The result of research indicate that Stuctural Analitycal Synthetic (SAS) method is effective used in reading learning which shown trhough observation result of teacher activity with the percentage of cycle $I=65,28 \%$, cycle $I I=91,67 \%$, and cycle $I I I=100 \%$. Observation result of students activities with percentage of cycle $I=74,44 \%$, cycle $I I=76,67 \%$, and cycle III $=80 \%$. While improving students reading skills is derived from the average post test result, pre cycle $=68,14 \%$ with a percentage of completeness $46,43 \%$, cycle $I=77,53 \%$ with a percentage of
\end{abstract}


completeness $67,86 \%$, cycle $I I=87,11 \%$ with a percentage of completeness $89,29 \%$, and cycle $I I I=$ $91,39 \%$ with a percentage of completeness $100 \%$ from 28 students. Thus it can be concluded that the Stuctural Analitycal Synthetic (SAS) method is effectively used and can improve the reading skills of first grade students of MI Nurul Islamiyah Kemang.

Keywords: Effectiveness, Stuctural Analitycal Synthetic (SAS) method, Skill, Reading.

\section{Pendahuluan}

Keterampilan adalah potensi yang ada di dalam diri manusia dan harus dikembangkan secara mendalam agar potensi yang tersebut terealisasikan. Menurut Sudarto (2016), keterampilan yaitu kemampuan untuk menggunakan akal, fikiran, ide, kreatifitas dalam mengerjakan, mengubah atau membuat sesuatu menjadi lebih bermakna sehingga menghasilkan sebuah nilai dari hasil pekerjaan tersebut. Keterampilan sangat beragam salah satunya adalah keterampilan membaca keterampilan membaca ini memiliki manfaat luas bagi kehidupan manusia. Membaca adalah suatu aktivitas atau kegiatan yang merupakan alat bagi guru, murid, ataupun pembaca bersama-sama dengan orang lain atau pendengar untuk menangkap serta memahami informasi, pikiran, dan perasaan seseorang atau pengarang Henry (2015). Adapun menurut Novi dan Dadan (2007), membaca mencakup 3 peran yaitu membaca merupakan suatu proses, membaca adalah strategis, dan membaca merupakan kegiatan interaktif. Selain itu membaca dapat dilihat sebagai suatu proses dan sebagai suatu hasil. Membaca sebagai suatu proses merupakan semua kegiatan dan teknik yang ditempuh oleh pembaca yang mengarah pada tujuan melalui tahap-tahap tertentu. Proses tersebut berupa penyandian kembali dan penafsiran sandi. Kegiatannya dimulai dari mengenal huruf, kata, ungkapan, frasa, kalimat, dan wacana, serta menghubungkannya dengan bunyi dan maknanya Burns dalam Khundaru dan Slamet (2014). Pendapat lain Bond dalam Mulyono (2012), menyimpulkan bahwa membaca merupakan pengenalan simbol-simbol bahasa tulis dari yang merupakan stimulus yang membantu proses mengingat tentang apa yang dibaca, untuk membangun suatu pengertian melalui pengalaman yang telah dimiliki.

Keterampilan berbahasa ini merupakan suatu keterampilan yang sangat unik serta berperan penting bagi pengembangan pengetahuan, dan sebagai alat komunikasi bagi kehidupan manusia. Dikatakan unik karena tidak semua manusia walaupun telah memiliki keterampilan membaca, mampu mengembangkannya menjadi alat untuk memberdayakan dirinya atau bahkan menjadikannya budaya bagi dirinya sendiri. Dikatakan penting bagi pengembangan pengetahuan karena presentase transfer ilmu pengetahuan terbanyak dilakukan melalui membaca Iskandarwassid dan Dadang (2016). Mulyono (2012), menyatakan ada empat kelompok karakteristik kesulitan belajar membaca, yaitu kebiasaan membaca, kekeliruan mengenal kata, kekeliruan pemahaman dan gejala-gejala serbaneka. Sementara hasil penelitian fakta di lapangan menunjukkan kompetensi membaca generasi muda Indonesia sangat memprihatinkan. Programme For International Student Assessment (PISA) di bawah Organization Economic Cooperation and Development (OECD) pada tahun 2012 lalu mengeluarkan survei bahwa Indonesia menduduki peringkat 10 besar paling bawah dari 65 negara dalam pemetaan kemampuan membaca yang dipublikasikan dalam Jurnal Bakti Saraswati (2015).

Adapun Laporan Bank Dunia No.16369-IND, dan Studi IEA (International Association for the Evalution of Education Achievermen) di Asia Timur, menunjukkan 
bahwa tingkat terendah membaca anak-anak dipegang oleh negara Indonesia. Kajian PILRS (Progress in International Reading Literacy Study) yaitu pada anak-anak diseluruh dunia yang disponsori oleh IEA ini menunjukkan bahwa rata-rata anak Indonesia berada pada urutan keempat dari bawah dari 45 negara di dunia dipublikasikan dalam Jurnal Pendidikan Bahasa dan Sastra Indonesia FKIP Universitas Islam Malang (2010). Peneliti juga menemukan permasalahan mengenai rendahnya kemampuan keterampilan membaca di kelas I MI Nurul Islamiyah Kemang. Permasalahan tersebut belum mendapatkan solusi yang tepat untuk menanganinya, peneliti berupaya memberikan solusi untuk meningkatkan keterampilan membaca dengan menerapkan metode structural analytical synthetic (SAS).

Menurut Zahrul (2017) metode sructural analitycal synthetic (SAS) merupakan salah satu jenis metode yang bisa digunakan untuk proses pembelajaran membaca dan menulis permulaan bagi peserta didik pemula. Metode structural analitycal synthetic (SAS) didasarkan atas asumsi bahwa pengamatan anak mulai dari keseluruhan (Gestalt) dan kemudian ke bagian-bagian. Oleh karena itu, anak diajak memecahkan kode tulisan dalam kalimat pendek yang dianggap sebagai unit bahasa utuh. Selanjutnya diajak menganalisis menjadi kata, suku kata, dan huruf. Kemudian mensintesiskan kembali dari huruf ke suku kata, kata, dan akhirnya menjadi kalimat metode ini digunakan secara luas di Indonesia Mulyono (2010). Menurut Yeti (2010), kelebihan metode sructural analitycal synthetic (SAS) yaitu sejalan dengan prinsip linguistik (ilmu bahasa), mempertimbangkan pengalaman bahasa anak, dan sesuai dengan prinsip inquiri atau menemukan sendiri.

Jadi rumusan masalah dan tujuan penelitian ini adalah untuk mengetahui kemampuan keterampilan membaca peserta didik kelas I MI Nurul Islamiyah Kemang dan efektifitas penerapan metode pembelajaran structural analitycal synthetic (SAS) dalam meningkatkan keterampilan membaca pada peserta didik kelas rendah di MI Nurul Islamiyah Kemang.

\section{Metode Penelitian}

Jenis metode penelitian yang digunakan adalah penelitian tindakan kelas (PTK). Penelitian ini dilaksanakan dalam 3 siklus, prosedur tindakan yang peneliti rencanakan melalui empat tahapan yaitu perencanaan tindakan (plan), pelaksanaan tindakan (act), pengamatan terhadap tindakan (observe), dan refleksi terhadap tindakan (reflect) atau disingkat PAOR dilakukan pada setiap siklus (Sukardi, 2015).

Subjek penelitian dalam penelitian ini yaitu peserta didik kelas I MI Nurul Islamiyah Kemang tahun pelajaran 2017/2018 dengan jumlah peserta didik sebanyak 28 orang. Teknik pengumpulan data dalam penelitian ini dilakukan dengan teknik observasi, tes, dan dokumentasi. Analisis data yang digunakan yaitu analisis secara deskriptif, sedangkan teknik analisisnya menggunakan dua jenis data yaitu kuantitatif dan kualitatif. Data kuantitatif adalah data berupa nilai rata-rata hasil peningkatan membaca peserta didik yang diperoleh dari hasil pretest dan posttest pada setiap siklus, sedangkan data kualitatif adalah data yang bersifat induktif yaitu analisis data berdasarkan data yang diperoleh. Analisis dilaksanakan setelah pengumpulan data berupa lembar observasi aktivitas guru dan peserta didik selama proses tindakan pembelajaran pada setiap siklus. 


\section{Hasil dan Pembahasan}

\section{1. Hasil}

Sebelum melaksanakan penelitian tindakan kelas di kelas I MI Nurul Islamiyah Kemang, peneliti mengadakan observasi dan melakukan pretest. Dari hasil pretest banyak peserta didik yang belum menguasai keterampilan membaca dengan lancar dan baik, hasil pretest dapat dilihat pada tabel dan grafik di bawah ini.

\begin{tabular}{|c|c|c|}
\hline $\begin{array}{c}\text { Jumlah Peserta } \\
\text { didik }\end{array}$ & Presentase & Kategori \\
\hline 15 & $53,57 \%$ & Belum Tuntas \\
\hline 13 & $46,43 \%$ & Tuntas \\
\hline
\end{tabular}

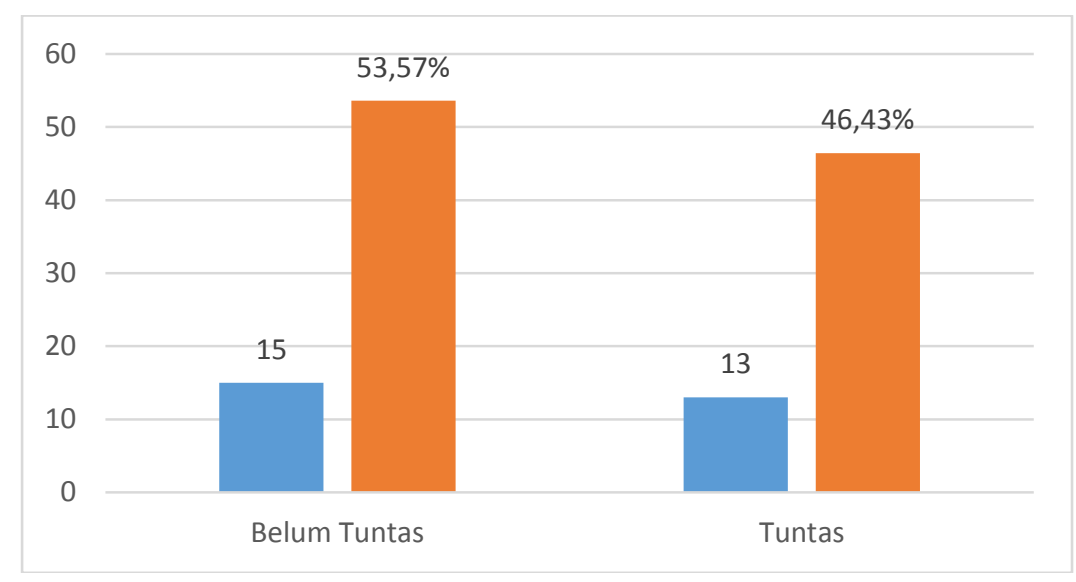

Gambar 1. Grafik ketuntasan keterampilan membaca pra siklus

Berdasarkan tabel dan grafik pra siklus diperoleh bahwa nilai presentase peserta didik yang belum mencapai ketuntasan sebesar 53,57\% atau 15 peserta didik dari 28 peserta didik. Sedangkan nilai presentase peserta didik yang mencapai ketuntasan yaitu 46,43\% atau 13 peserta didik. Maka dari hasil pretest tersebut perlu diadakan tindakan siklus I.

Tindakan siklus I dilaksanakan dengan beberapa tahap, yaitu tahap perencanaan tindakan (plan), tahap pelaksanaan tindakan (act), tahap pengamatan tindakan (observen), dan tahap refleksi (reflect). Hasil pengamatan berdasarkan observasi aktivitas guru pada siklus I memperoleh nilai presentase sebesar 65, 28\% dan aktivitas peserta didik pada sisklus I memperoleh hasil presentase yaitu 74,44\%, hasil tersebut dikatakan metode Structural Analitycal Synthetic (SAS) efektif. Sedangkan untuk hasil posttest kemampuan keterampilan membaca peserta didik pada siklus I dapat dilihat pada tabel dan grafik berikut 
Tabel 2. Ketuntasan Keterampilan Membaca Peserta didik Siklus I

\begin{tabular}{ccc}
\hline $\begin{array}{c}\text { Jumlah Peserta } \\
\text { didik }\end{array}$ & Presentase & Kategori \\
\hline 9 & $32,14 \%$ & Belum Tuntas \\
\hline 19 & $67,86 \%$ & Tuntas \\
\hline
\end{tabular}

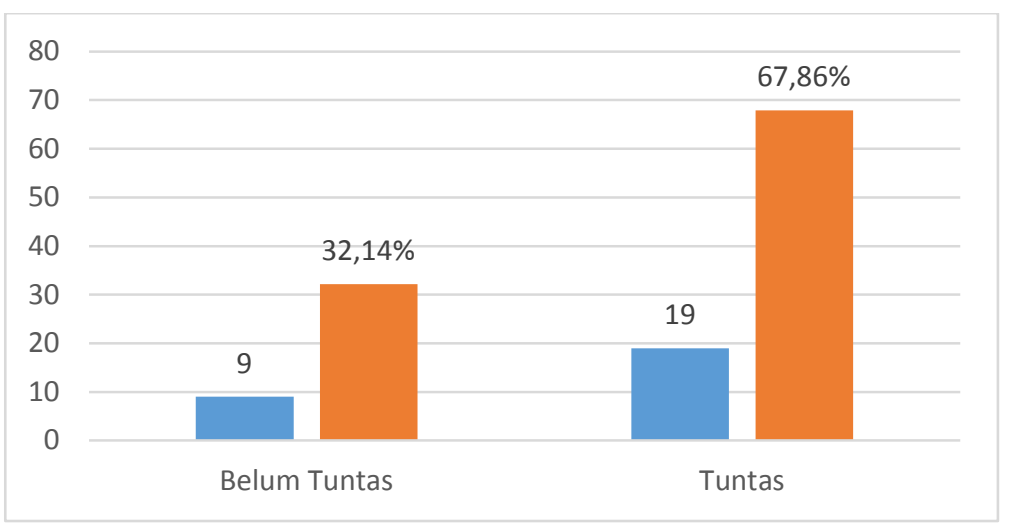

Gambar 2. Grafik ketuntasan keterampilan membaca siklus I

Berdasarkan tabel dan grafik siklus I diperoleh bahwa nilai presentase peserta didik yang belum mencapai ketuntasan sebesar 32,14\% atau 9 peserta didik dari 28 peserta didik. Sedangkan nilai presentase peserta didik yang mencapai ketuntasan yaitu $67,86 \%$ atau 19 peserta didik. Maka dari hasil posttest tersebut terdapat peningkatan pada kemampuan keterampilan membaca peserta didik. Setelah melakukan refleksi peneliti dan kolaborator bersepakat bahwa masih perlu adanya perbaikan tindakan siklus II.

Selanjutnya siklus II juga dilaksanakan dengan empat tahap yaitu tahap perencanaan tindakan (plan), tahap pelaksanaan tindakan (act), tahap pengamatan tindakan (observe), dan tahap refleksi (reflect). Hasil pengamatan berdasarkan observasi aktivitas guru pada siklus II memperoleh nilai presentase sebesar 91,67\% dan aktivitas peserta didik pada sisklus II memperoleh hasil presentase yaitu 76,67\%. Pada hasil pengamatan siklus II terdapat peningkatan yang signifikan dari siklus I, maka dapat dinyatakan metode structural analytical synthetic (SAS) efektif digunakan dalam pembelajaran membaca. Sementara hasil posttest peserta didik pada siklus II dapat dilihat pada tabel dan grafik di bawah ini:

Tabel 3. Ketuntasan Keterampilan Membaca Peserta didik Siklus II

\begin{tabular}{ccc}
\hline $\begin{array}{c}\text { Jumlah Peserta } \\
\text { didik }\end{array}$ & Presentase & Kategori \\
\hline 9 & $32,14 \%$ & Belum Tuntas \\
\hline 19 & $67,86 \%$ & Tuntas \\
\hline
\end{tabular}




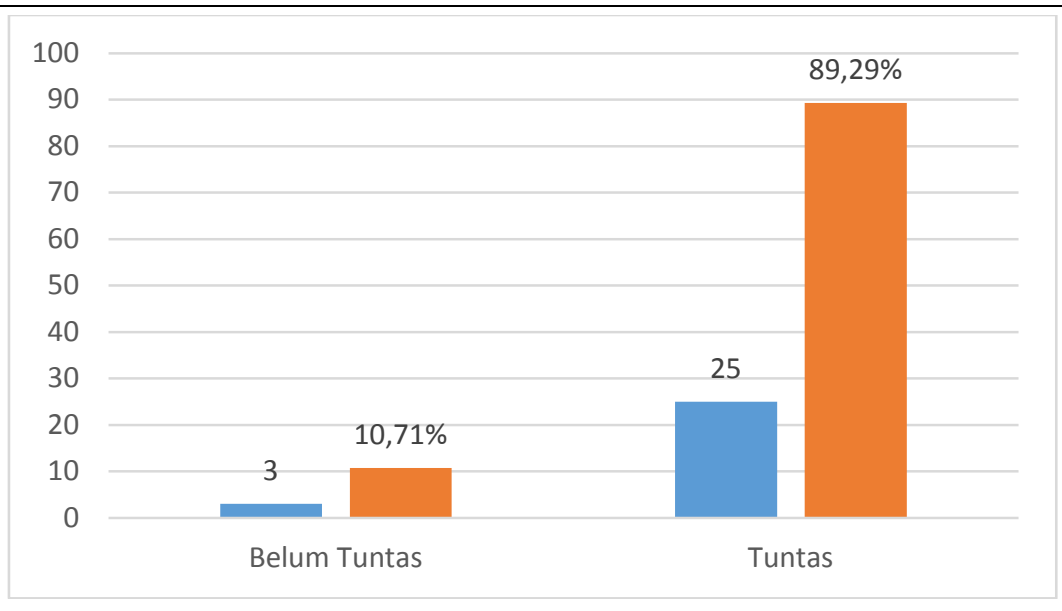

Gambar 3. Grafik ketuntasan keterampilan membaca siklus II

Dari tabel dan grafik siklus II diketahui nilai rata-rata presentase peserta didik yang belum mencapai ketuntasan sebesar 10,71\% atau 3 peserta didik dari 28 peserta didik. Sedangkan nilai rata-rata presentase peserta didik yang mencapai ketuntasan yaitu 89,29\% atau 25 peserta didik. Maka dari hasil posttest tersebut terdapat peningkatan yang baik pada kemampuan keterampilan membaca peserta didik, setelah melakukan refleksi peneliti dan kolaborator bersepakat untuk melakukan peningkatan kembali melalui tindakan siklus III.

Pada siklus III pelaksanaan tindakannya sama dengan tindakan pada siklus II. Dari hasil pengamatan berdasarkan observasi aktivitas guru pada siklus II memperoleh nilai presentase sebesar $100 \%$ dan aktivitas peserta didik pada sisklus II memperoleh hasil presentase yaitu $80 \%$. Pada hasil pengamatan siklus III terdapat peningkatan sesuai dengan yang diharapkan, maka dinyatakan metode structural analytical synthetic (SAS) efektif digunakan dalam pembelajaran membaca di kelas I MI Nurul Islamiyah Kemang. Hasil posttest peserta didik pada siklus III dapat dilihat pada tabel dan grafik berikut:

Tabel 4. Ketuntasan Keterampilan Membaca Peserta didik Siklus II

\begin{tabular}{ccc}
$\begin{array}{c}\text { Jumlah Peserta } \\
\text { didik }\end{array}$ & Presentase & Kategori \\
\hline 0 & $0 \%$ & Belum Tuntas \\
\hline 28 & $100 \%$ & Tuntas \\
\hline
\end{tabular}




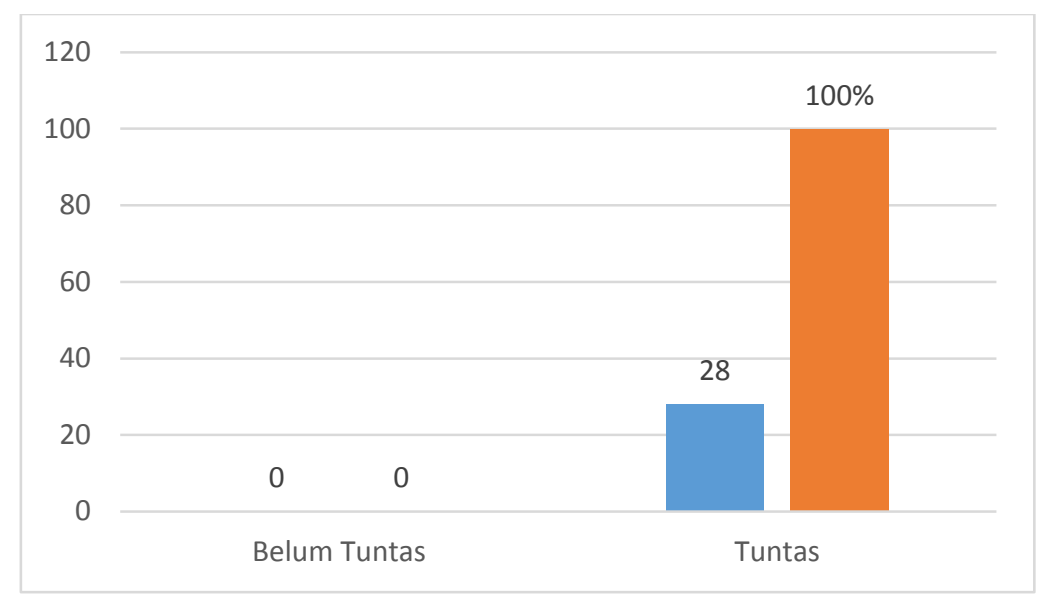

Gambar 4. Grafik ketuntasan keterampilan membaca siklus III

Dari tabel dan grafik siklus III diperoleh nilai presentase peserta didik yang belum mencapai ketuntasan sebesar $0 \%$ atau 0 . Sedangkan nilai presentase peserta didik yang mencapai ketuntasan yaitu $100 \%$ atau mencapai jumlah keseluruhan peserta didik kelas I yaitu 28 peserta didik. Pada siklus III terjadi peningkatan yang sangat memuaskan dan sesuai harapan. Setelah melakukan kegiatan refleksi peneliti dan kolaborator bersepakat bahwa penelitian tindakan kelas ini sudah cukup dan terselesaikan pada tindakan siklus III.

\section{2. Pembahasan}

Berdasarkan seluruh kegiatan penelitian tindakan kelas (PTK) yang dilakukan di kelas I MI Nurul Islamiyah Kemang dapat diketahui bahwa metode stuctural analytical synthetic (SAS) efektif digunakan dalam pembelajaran membaca dan dapat meningkatkan kemampuan keterampilan membaca peserta didik. Efektifitas metode SAS ditunjukkan dengan perolehan nilai presentase hasil observasi guru yang meningkat dari $68,28 \%$ siklus I, 91,67\% siklus II, dan $100 \%$ siklus III, dan hasil observasi peserta didik yang meningkat dari 74,44\% siklus I, 76,67\% siklus II, dan $80 \%$ siklus III. Sedangkan peningkatan keterampilan membaca peserta didik dapat dilihat dari hasil ketuntasan keterampilan membaca pada pretest dan posttest yaitu dari $46,43 \%$ pra siklus, $67,86 \%$ siklus I, 89,29\% siklus II, dan $100 \%$ siklus III.

\section{Kesimpulan}

Berdasarkan hasil penelitian tindakan kelas (PTK) yang diperoleh dari data pretest, posttest, dan pengamatan (observasi) aktivitas guru dan peserta didik pada kelas I MI Nurul Islamiyah Kemang dapat disimpulkan bahwa metode stuctural analytical synthetic (SAS) efektif digunakan dalam pembelajaran membaca dan dapat meningkatkan keterampilan membaca peserta didik kelas I MI Nurul Islamiyah Kemang.

\section{Daftar Pustaka}

Agung P., M. (2015). Meningkatkan Pemahaman Membaca Peserta didik Melalui Strategi Affinity dan Materi Bacaan Otentik. Jurnal Bakti Saraswati, 4, 10. 
Henry, G., T. (2015). Membaca Sebagai Suatu Keterampilan Berbahasa (edisi revisi). Bandung: CV Angkasa.

Iskandarwassid, D., S. (2016). Strategi Pembelajaran Bahasa. Bandung: Remaja Rosdakarya.

Kundharu, S., S. (2014). Pembelajaran Keterampilan Berbahasa Indonesia: Teori Aplikasi. Yogyakarta: Graha Ilmu.

Mulyono, A. (2012). Anak Berkesulitan Belajar Teori, Diagnosis, dan Remediasinya. Jakarta: Rineka Cipta.

Novi, R., Dadan, J. (2007). Pendidikan Bahasa dan Sastra Indonesia di Kelas Tinggi (edisi kesatu). Bandung UPI PRESS.

Sudarto. (2016). Keterampilan dan Nilai Sebagai Materi Pendidikan dalam Perspektif Islam. Jurnal Al Lubab, 1, 107.

Sukardi. (2015). Metode Penelitian Pendidikan Tindakan Kelas Implementasi dan Pengembangannya. Jakarta: Bumi Aksara.

Wahyuni, S. (2010). Menumbuhkan Minat Baca Menuju Masyarakat Literat. Jurnal Pendidikan Bahasa dan Sastra Indonesia FKIP Universitas Islam Malang, 17, 180.

Zahrul, W. (2017). Penerapan Metode SASMG (Stuktural Analitikal Sintetik dan Metode Global) untuk Meningkatkan Motivasi dan Hasil Belajar Peserta Didik Pada Mata Pelajaran Bahasa Indonesia Kelas I di SDN 3 Kopang Kec. Kopang Tahun Pelajaran 2015/2016. Jurnal Ilmiah Mandala Education, 3, 52. 